\title{
THE INFLUENCE OF WEFT DENSITY, WEFT YARN COUNT AND FINISHING ON SLIPPAGE RESISTANCE OF YARNS AT SEAM
}

Maja Jankoska*, Goran Demboski

(ORIGINAL SCIENTIFIC PAPER)

UDC 687.053.665:677.072

University "Ss. Cyril and Methodius", Faculty of Technology and Metallurgy, Department of Textile, Skopje, Macedonia

The effect of weft density, weft yarn count and waterproof and oilproof finishing on the seam slippage properties were investigated for a range of fabrics for tailored garments. It was shown that the increase of the weft density positively affects the seam slippage performance, while the effects depend on the magnitude of increasing the weft density and a testing direction. The introduction of a higher weft yarn count results in the improved warp slippage performance. As a result of the higher weft yarn count, the seam opening decreased for $40 \%$ for warp slippage. The fabrics having waterproof and oilproof finishing showed worsened seam slippage properties. The analysis of variance confirmed that weft density, weft yarn count and waterproof and oilproof finishing are statistically significant factors on the seam opening as a result of the yarn slippage of yarns at seams.
Keywords: seam slippage, seam opening, waterproof and oilproof finishing

\section{Introduction}

A key success factor for garment manufacturers in today global market is the ability to constantly create innovative and high performance products. This requires research into market needs, accompanied with the production and process innovation capability, expertise in technology and quality of manufacture. So, today textile consumers are well aware of the market trends and have high demands for innovative products accompanied with high quality and performance. The garment quality and performance rely on various factors such as: fabric quality, sewing quality and usage quality. The seam slippage which frequently occurs in furniture upholstery fabrics parallel to sewing line, results in partial or full distortion of the fabric appearance. Galuszynski [1] investigated the seam slippage mechanism in woven fabrics theoretically and showed that the seam slippage or fabric resistance to seam slippage results from: the friction between fabric yarns and sewing yarns; the bending rigidity of fabric yarns; and the structure and density of the fabric and stitch. Kalaoglu et al. [2] have obtained the same results and have shown experimentally that the seam slippage is related to the fabric structure and the density of weft yarns. Prior to this, Shimazaki et al. [3] proposed the use of an empirical equation for calculating the seam slippage depending upon the sewing length, loading and the axis of loading. Behera et al. [4] emphasized that the seam slippage is related to mechanical properties of fabric and seam threads. Gurarda et al. [5] showed that the reduction of the weft density results in the increase of the seam slippage. In other study, [6] it was shown that seam properties are related to the structure and density of the fabric, linear density of the sewing yarns, needle parameters and the seam type. Miguel et al. [7] investigated the dependence of the seam slippage in wool fabrics upon structural properties of fabrics, and claimed that it is possible to design wool fabrics with the optimum seam slippage. Domingues et al. [8] studied the changes in dependence of the fabric strength and elongation to break; seam strength and slippage; seam efficiency; opening limits of seams and both modulus at $1 \mathrm{~mm}$ and at break, along the fatigue cycles upon the periodical washing, drying and ironing processes. They analyzed the results obtained in function of the seam directions and fatigue cycles. Yildirim [9] showed that stitch density, yarn linear density, and the number of weft yarns per unit length are important parameters, causing the seam slippage.

There are also numerous studies [10] on the seam quality based on the aesthetic performance. However, these studies focus mainly on the seam defects such as the seam puckering and the seam damage. Furthermore, few studies have evaluated the seam quality from both aspects of the seam: functional and aesthetic [11]. Malčiauskienè et al. [12] investigated the influence of the weave, warp density and weft density on the seam slippage in the woven fabric. It was found that the warp density has a very low influence on seam slippage characteristics. Only the weft density and weave influence the seam slippage. Brnada et al. [13] have investigated the influence of the weave and thread density of the woven fabric on the damage amount of the fabric in the seam area when subjected to the tensile strength (seam slippage). The results show that the surface of the resulting "hole" depends on the density of warp and weft

\footnotetext{
* Author address: Maja Jankoska, Faculty of Technology and Metallurgy, Rudjer Boskovic 16, 1000 Skopje, Macedonia

E-mail: maja@tmf.ukim.edu.mk

The manuscript received: September, 26, 2017.

Paper accepted: November, 30, 2017.
} 
and the weave of the fabric. Bačkauskaite et al. [14] suggested new methods for the investigation of the yarn slippage at the sewn seam in woven fabrics, and for the determination of the parameters of yarn pulling out from woven fabrics based on the analysis of friction between fabric yarn systems. The obtained results of the yarn pulling out from the sewn woven fabric are significant to explain the yarn slippage at the sewn seam in woven fabrics in respect to a friction aspect. Özdemir et al. [15] determined the effects of the selected yarn and fabric structural parameters on the seam slippage strength, abrasion resistance and propensity to surface fuzzing and pilling of certain double woven upholstery fabrics. The seam slippage strength along warp and weft directions and the abrasion resistance of upholstery double fabrics woven with staple polyester weft yarns have been higher than those of upholstery double fabrics woven with the cotton weft yarn.

The aim of the paper is further investigation of the influence of the weft yarn density and count on the seam slippage. Now, the idea is to investigate small percentage of the increased weft density, just above $5 \%$ and its influence on the seam slippage. Furthermore, the paper investigates the influence of the weft yarn count and structure variation (the increase of the weft yarn count and at the same time change the weft structure from single ply to double ply). In that context, the idea of the paper is to investigate the effect of oilproof and waterproof finishing on the seam slippage on wool blend fabrics.

\section{Experimental}

Materials and Method

The object of the investigation is a group worsted woven fabrics for outerwear garments. The details of the fabric structure parameters are shown in Table 1. The fabrics are arranged in five distinctive pairs of fabrics. Every second fabric in the pair is produced either by variation of fabric or yarn parameters (weft thread density or weft yarn count), or by the application of a particular finishing treatment.

The structure variation for pairs $\mathrm{A} / \mathrm{A} 1$ and $\mathrm{C} / \mathrm{C} 1$ is weft density. The samples $\mathrm{A} 1$ and $\mathrm{C} 1$ have higher weft density than its pair $A$ and $C$. All other structural parameters, fiber composition and finishing are kept the same for both fabrics in a pair.

The structure variation for the second pair of fabrics designated B and B1 is the weft yarn count and the yarn structure. Sample B has single ply weft yarn of the lower count, while B1 has double ply weft yarn of the higher count. Other parameters are also kept constant.

The fabrics of the fourth pair (D/D1) and fifth pair (E/E1) only differ in finishing. Namely, D and $E$ have standard clear cut finishing, while D1 and E1 have additional waterproof and oilproof finishing. All other parameters of both fabrics in pair are kept identical. Waterproof and oilproof finishing was carried out by teflon impregnation on a foulard, with an $80 \%$ degree of sizing, $25 \mathrm{~g} / \mathrm{l}$ Tubiguard $66,3 \mathrm{~g} / \mathrm{l}$ Tubiguard fix and $5 \mathrm{~g} / \mathrm{l}$ Collosal FD, followed by drying or thermal fixation at the temperature from $130{ }^{\circ} \mathrm{C}$ to $150^{\circ} \mathrm{C}$.

Regarding fiber composition, the first three pairs of fabrics have $100 \%$ wool or $100 \%$ wool and Lycra blend. Regarding weave, they are similar and have twill 2/1 weave or twill $2 / 2$ weave. Both the fourth and fifth pair of fabrics have an identical fiber composition: a blend of wool, PES and Lycra. These pairs have the identical warp and weft yarns count but different weave.

Table 1. Investigated fabric particulars

\begin{tabular}{|c|c|c|c|c|c|c|c|c|c|c|}
\hline Fabric & A & A1 & B & B1 & C & C1 & D & D1 & E & E1 \\
\hline $\begin{array}{l}\text { Fiber } \\
\text { composition }\end{array}$ & \multicolumn{2}{|c|}{$\begin{array}{l}98 \% \text { wool } \\
2 \% \text { Lycra }\end{array}$} & \multicolumn{2}{|c|}{$100 \%$ wool } & \multicolumn{2}{|c|}{$100 \%$ wool } & $\begin{array}{l}44 \% \\
54 \% \\
2 \%\end{array}$ & $\begin{array}{l}\text { wool } \\
\text { PES } \\
\text {-ycra }\end{array}$ & \multicolumn{2}{|c|}{$\begin{array}{l}44 \% \text { wool } \\
54 \% \text { PES } \\
2 \% \text { Lycra }\end{array}$} \\
\hline $\begin{array}{l}\text { Warp count, } \\
\text { tex }\end{array}$ & \multicolumn{2}{|c|}{$17 \times 2$} & \multicolumn{2}{|c|}{$15 \times 2$} & \multicolumn{2}{|c|}{$17 \times 2$} & \multicolumn{2}{|c|}{$18 \times 2$} & \multicolumn{2}{|c|}{$18 \times 2$} \\
\hline $\begin{array}{l}\text { Weft count, } \\
\text { tex }\end{array}$ & \multicolumn{2}{|c|}{$17 \times 2$} & 24 & $15 \times 2$ & \multicolumn{2}{|c|}{$17 \times 2$} & \multicolumn{2}{|c|}{$18 \times 2$} & \multicolumn{2}{|c|}{$18 \times 2$} \\
\hline $\begin{array}{l}\text { Warp density, } \\
\mathrm{cm}^{-1}\end{array}$ & \multicolumn{2}{|c|}{32} & \multicolumn{2}{|c|}{31.2} & \multicolumn{2}{|c|}{30.8} & \multicolumn{2}{|c|}{29} & \multicolumn{2}{|c|}{35.4} \\
\hline $\begin{array}{l}\text { Weft density, } \\
\text { cm }^{-1}\end{array}$ & 24.8 & 26.2 & 27.6 & 28 & 25.6 & 28.2 & \multicolumn{2}{|c|}{20} & \multicolumn{2}{|c|}{24.4} \\
\hline $\begin{array}{l}\text { Fabric } \\
\text { thickness, } \\
\text { mm }\end{array}$ & 0.36 & 0.41 & 0.29 & 0.34 & 0.39 & 0.41 & 0.39 & 0.39 & 0.45 & 0.45 \\
\hline $\begin{array}{l}\text { Fabric weight, } \\
\mathrm{g} / \mathrm{m}^{2}\end{array}$ & 213 & 227 & 167 & 187 & 213 & 227 & 200 & 200 & 250 & 250 \\
\hline Finishing & \multicolumn{2}{|c|}{ standard } & \multicolumn{2}{|c|}{ standard } & \multicolumn{2}{|c|}{ milled } & standard & $\begin{array}{l}\text { oilproof } \\
\text { waterproof }\end{array}$ & standard & $\begin{array}{c}\text { oilproof } \\
\text { waterproof }\end{array}$ \\
\hline Weave & \multicolumn{2}{|c|}{$2 \times 1$ twill } & \multicolumn{2}{|c|}{$2 \times 1$ twill } & \multicolumn{2}{|c|}{$2 \times 2$ twill } & \multicolumn{2}{|c|}{ plain } & \multicolumn{2}{|c|}{$2 \times 2$ twill } \\
\hline
\end{tabular}

The fabrics were tested for the seam slippage according to BS 3320 [16], and the tests were performed on the SCHENCK tensile testing machine. The pieces of the test fabric were sewn together using single-needle, lock-stitch sewing machine capable of producing type stitch 301, (Figure 1). The samples were prepared as in Figure 2. The fabric samples were conditioned at standard atmosphere conditions $\left(20 \pm 2{ }^{\circ} \mathrm{C}, 65 \pm 2 \%\right.$ relative humidity) for 24 hours. 


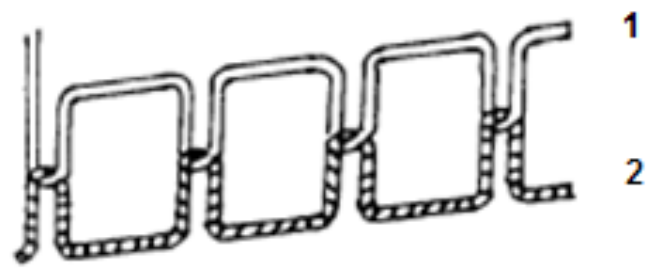

Figure 1. Stitch type: 1- needle thread, 2 - bobbin thread

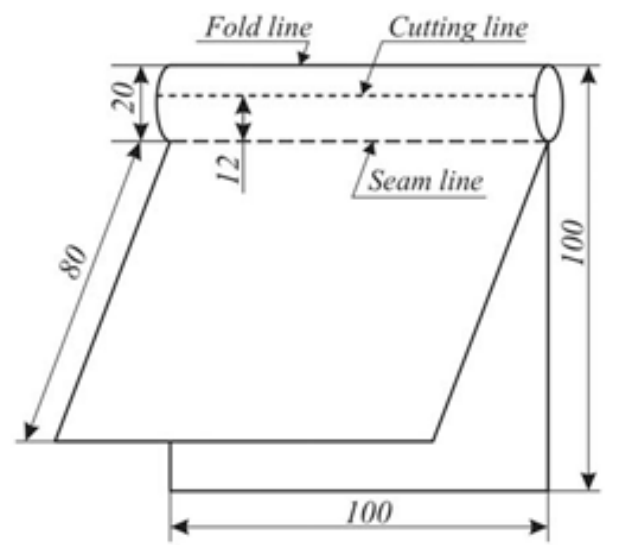

Figure 2. Schematic of the sample preparation (Sizes are in $\mathrm{mm}$ )

The test comprises tensile testing of the unseamed and seamed fabric samples which are superimposed on the same chart. The distance parallel to horizontal axis of $3 \mathrm{~mm}$ between two stress strain curves in the region till $200 \mathrm{~N}$ force is registered as the seam slippage. If the distance between two curves does not reach $3 \mathrm{~mm}$ in the region till $200 \mathrm{~N}$, that result is registered as more than $200 \mathrm{~N}$. Five specimens of each fabric were prepared for the tests.

\section{Results and discussion}

The results of the testing fabric for the seam slippage are presented in Table 2.

For the weft slippage (Table 2), the sample A shows no indices of the seam slippage till $200 \mathrm{~N}$ force, in two out of five tests, while in three cases there is a registration of the seam slippage. In three cases sthe ample A1 (higher weft density) shows no seam slippage till $200 \mathrm{~N}$ force. The somewhat better result of $A 1$ compared to $A$ is the result of higher weft density (Table 2). For the warp slippage, we have a clearer effect of the increased weft density on the seam slippage for the pair A/A1. Namely, fabric A shows the seam slippage in all five tests, while sample $A 1$ (higher weft density) show no seam slippage in two out of five tests and, in three cases the seam slippage force is higher compared to A. At the warp slippage, warp slides over weft yarns. The increase of the weft density in turn increases warp contact points with weft and warp crimp, which decreases the ability of the warp to sleep over weft, and results in the improved seam slippage performance. So the increase of the weft density generally results in a better seam slippage performance, which is more pronounced for the warp slippage.

The pair $\mathrm{C} / \mathrm{C} 1$ shows similar results for the weft slippage as the pair A/A1. Namely, the average force of fabric $C$ with a lower weft density is $115.5 \mathrm{~N}$, while in fabric $\mathrm{C} 1$ with a higher weft density it is $128 \mathrm{~N}$. Regarding the warp slippage, the sample $C$ (lower density) in all five tests shows the seam slippage, while the sample C1 (higher weft density) in two of five samples has no occurrence of the seam slippage till the force of $200 \mathrm{~N}$ is reached.

Table 2. Seam slippage resistance of yarns at the seam for $3 \mathrm{~mm}$ seam opening

\begin{tabular}{ccccccccccc}
\hline Sample & & \multicolumn{10}{c}{ Weft slippage, N } & & & & \\
& A & A1 & B & B1 & C & C1 & D & D1 & E & E1 \\
\hline $\mathbf{1}$ & $>200$ & $>200$ & 197.5 & 140 & 85 & 180 & 120 & 167.5 & 155 & 185 \\
$\mathbf{2}$ & $>200$ & 125 & 160 & 150 & 140 & 100 & 192.5 & 100 & $>200$ & 137.5 \\
$\mathbf{3}$ & 150 & 137.5 & 130 & 150 & 107.5 & 125 & 190 & 195 & 160 & 185 \\
$\mathbf{4}$ & 175 & $>200$ & 140 & 150 & 110 & 142.5 & 182.5 & 135 & $>200$ & $>200$ \\
$\mathbf{5}$ & 87.5 & $>200$ & 175 & 160 & 115 & 92.5 & 195 & 95 & $>200$ & 185 \\
& - & - & 160.5 & 150 & 115.5 & 128 & 176 & 138.5 & - & - \\
\hline & & & & & Warp slippage, N & & & \\
& $\mathbf{A}$ & A1 & B & B1 & C & C1 & D & D1 & E & E1 \\
\hline $\mathbf{1}$ & 50 & 187.5 & 100 & $>200$ & 87.5 & 87.5 & 190 & $>200$ & 37.5 & 55 \\
$\mathbf{2}$ & 75 & $>200$ & 92.5 & 187.5 & 87.5 & $>200$ & 70 & 80 & 135 & 125 \\
$\mathbf{3}$ & 25 & $>200$ & 102.5 & 187.5 & 70 & $>200$ & 172.5 & 82.5 & 25 & 60 \\
$\mathbf{4}$ & 95 & 175 & 60 & 170 & 112.5 & 107.5 & 150 & 95 & 25 & 10 \\
$\mathbf{5}$ & 87.5 & 137.5 & 70 & 150 & 75 & 75 & 75 & 95 & 175 & 187.5 \\
& 66.5 & - & 85 & - & 86.5 & - & 131.5 & - & 79.5 & 87.5 \\
\hline
\end{tabular}


Both fabrics in the second pair, where variation is increasing the weft yarn count, show the seam slippage below $200 \mathrm{~N}$ for the weft slippage testing. Sample B1 (higher weft count) shows a lower seam slippage force than B. Quite opposite, when testing the warp slippage, the sample of the higher weft count B1 for all tested samples shows a higher seam slippage force compared to $\mathrm{B}$, while in one case, there is no seam opening till $200 \mathrm{~N}$ force is reached (Table 2).

The comparison of the results of the samples D/D1 in the weft slippage show that fabric $D$ having standard finishing shows a $27 \%$ higher force (176 N), compared to samples D1 of waterproof and oilproof finishing (138.5 N). Regarding the warp slippage, both samples obtain similar values.
The similar behavior is found for samples $E / E 1$. In the weft slippage, sample $E$ (standard finishing) in three out of five tests has no $3 \mathrm{~mm}$ opening till $200 \mathrm{~N}$ force, while E1 in two out of five test shows no slippage. Regarding the warp slippage, both samples show similar properties. Since the results of the seam slippage are difficult to compare when the results over $200 \mathrm{~N}$ are got, the seam opening is measured at $200 \mathrm{~N}$ force. The results are depicted in Table 3 and Figure 3 for the weft slippage and Figure 4 for the warp slippage.

Table 3. Seam opening at $200 \mathrm{~N}$ force

\begin{tabular}{|c|c|c|c|c|c|c|c|c|c|c|}
\hline Sample & A & A1 & B & B1 & C & C1 & D & D1 & E & E1 \\
\hline & \multicolumn{10}{|c|}{ Weft slippage } \\
\hline $\mathbf{x}_{1}, \mathrm{~mm}$ & 2.7 & 2.7 & 3 & 3 & 3.7 & 3.4 & 2.8 & 3.3 & 2.7 & 2.8 \\
\hline $\mathrm{SD}, \mathrm{mm}$ & 0.15 & 0.16 & 0.16 & 0.14 & 0.13 & 0.08 & 0.11 & 0.11 & 0.10 & 0.16 \\
\hline \multirow[t]{2}{*}{ CV, \% } & 5.50 & 5.90 & 5.30 & 4.70 & 3.50 & 2.40 & 3.90 & 3.30 & 3.70 & 6.00 \\
\hline & \multicolumn{10}{|c|}{ Warp slippage } \\
\hline $\mathbf{x}_{2}, \mathbf{m m}$ & 4.5 & 2.7 & 4.5 & 2.5 & 4.3 & 3.3 & 3.5 & 3.5 & 4.5 & 5 \\
\hline $\mathrm{SD}, \mathrm{mm}$ & 0.11 & 0.13 & 0.20 & 0.11 & 0.15 & 0.15 & 0.13 & 0.10 & 0.13 & 0.20 \\
\hline CV, \% & 2.50 & 4.80 & 4.40 & 4.30 & 3.50 & 4.50 & 3.80 & 2.90 & 2.90 & 4.00 \\
\hline
\end{tabular}

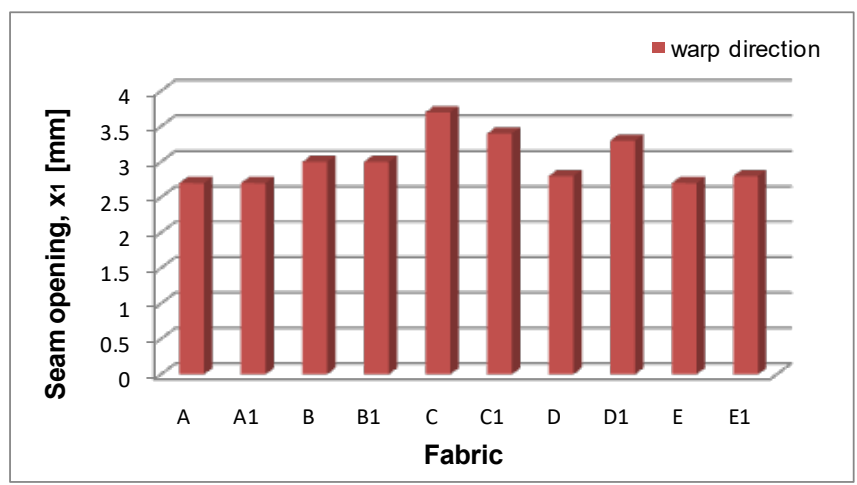

Figure 3. Seam opening at $200 \mathrm{~N}$ force for the weft slippage

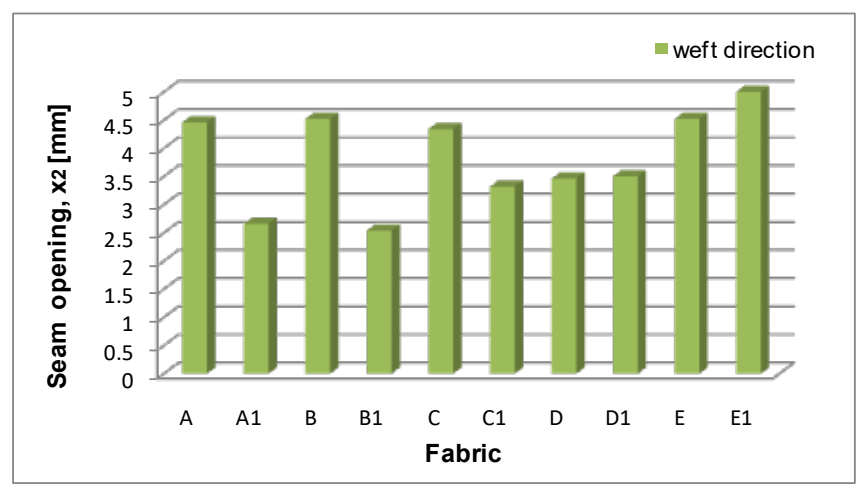

Figure 4. Seam opening at $200 \mathrm{~N}$ force for the warp slippage

For the weft slippage testing we see that the increase of the weft density has no effect on the seam opening for pair A/A1, while for pair $C / C 1$, there is a slight decrease of the seam opening from 3.7 to $3.4 \mathrm{~mm}$. The somewhat greater effect of the increase of the weft density on the seam opening for the pair $\mathrm{C} / \mathrm{C} 1$ can be explained by a greater increase of the weft density for this pair. For the warp slippage, the increase of the weft density results in a decrease of the seam opening for pair A/A1 from 4.5 to $2.7 \mathrm{~mm}(40 \%)$ and for pair $\mathrm{C} / \mathrm{C} 1$ from 4.3 to $3.3 \mathrm{~mm}$ (24\%) (Table 3, Figure 4 ). So, the increase of the weft density creates a greater contact of the warp yarn with weft and greater warp crimp which decrease the ability of the warp to slide over the weft.

The increase of the weft yarn count (B/B1) shows no effect on the seam opening for the weft slippage (Table 3 , Figure 3). But, when testing the warp slippage, we see that the increase of weft yarn count results in a great decrease of the seam opening from 4.5 to $2.5 \mathrm{~mm}$ (44.4\%). Again, the effect of increasing the weft yarn count is greater for the warp slippage, where warp slides over wefts, as a result of the increased contact length of the warp and weft due to the increase of the weft yarn count and diameter.

The fourth (D/D1) and fifth pair (E/E1) show similar behavior. The samples in both pairs with special finishing (waterproof and oilproof) obtain the increased seam opening in the weft and warp slippage, which is attributed to special finishing and the increased movement ability of the yarns.

The influence of the variation of fabric structural parameters or finishing on the seam opening due to the yarn slippage at the seam was analyzed by using the analysis of variance (ANOVA) given in Table 4. Fisher F- test values, and $p$-values (factors have a significant influence on the measured properties where $p<0.05$ ) for investigated parameters. 
Table 4. F-test for weft slippage (x1) and warp (x2) slippage

\begin{tabular}{|c|c|c|c|c|c|}
\hline Samples & A/A1 & B/B1 & $\mathrm{C} / \mathrm{C} 1$ & D/D1 & E/E1 \\
\hline Factor & Weft density & Weft thread count & Weft density & Finishing & Finishing \\
\hline & \multicolumn{5}{|c|}{ Weft slippage } \\
\hline$x_{1}$ & 0.36 & 0.83 & $14.52^{*}$ & $69.23^{*}$ & 1.94 \\
\hline \multirow[t]{2}{*}{ p } & 0.56 & 0.38 & 0.01 & 0 & 0.20 \\
\hline & \multicolumn{5}{|c|}{ Warp slippage } \\
\hline$x_{2}$ & $522.58^{*}$ & $356.4^{*}$ & $115.60^{*}$ & 0.28 & $20.21^{*}$ \\
\hline $\mathbf{p}$ & 0 & 0 & 0 & 0.60 & 0 \\
\hline
\end{tabular}

The results of F-test (Table 4) confirmed the impact of the weft density variation on the seam opening for the pair A/A1 only for the weft slippage and for the pair $\mathrm{C} / \mathrm{C} 1$ for the weft and warp slippage. The difference of the effect for pairs $A / A$ and $C / C 1$ can be attributed to a higher percentage of the weft density increase and the type of weave for these two pairs. Namely, the increase in the weft density is for $5.6 \%$ for A/A1 and $10.2 \%$ for $\mathrm{C} / \mathrm{C} 1$. The other reason can be a difference in the weave type. The A/A1 has twill 2/1, while C/C1 has twill 2/2 weave, which is more prone to the yarn slippage due to higher floating.

The test confirms a statistically significant influence of the weft yarn count variation on the fabric seam opening only for the warp slippage. The results also confirm that a finishing treatment is significant factor for the seam opening for the weft and warp slippage.

\section{Conclusion}

The variation of the fabric structure can affect the seam slippage or the yarns at the seam. The effects vary depending of the type of variation and a direction of testing.

The increase in the weft density results in improving the seam slippage. The results are more pronounced for the warp slippage. The increase of the weft density resulted in a decrease of the seam opening at the warp slippage for $40 \%$.

The higher weft yarn count positively affects the warp slippage performance. The insertion of a higher yarn count for the same weft density results in a $44.4 \%$ seam opening decrease.

The samples having waterproof and oilproof finishing showed the increased seam opening at $200 \mathrm{~N}$ force in the weft and warp slippage.

The analysis of variance (ANOVA) confirms that the weft density, weft yarn count and waterproof and oilproof finishing affects the seam slippage performance.

\section{References}

[1] S. Galuszynski, Some aspects of the mechanism of seam slippage in woven fabrics, Journal of Textile Institute, 76 (1985) 425-433.

[2] F. Kalaoglu, B. Meric, Investigation of the performance of linings, International Journal of Clothing Science and Technology, 17 (3/4) (2005) 171-178.

[3] K. Shimazaki, D.W. Lloyd, Opening behavior of lockstitch seams in woven fabrics under cyclic loading conditions, Textile Research Journal, 60(11) (1990) 654-662.

[4] B.K. Behera, Sewability of denim, International Journal of Clothing Science and Technology, 1997, 9(2) (1997) 128140.

[5] A. Gurarda, B. Meric, Slippage and grinning behavior of lockstitch seams in elastic fabrics under cyclic loading conditions, Tekstil ve Konfeksiyon, 20(1) (2010) 65-69.

[6] C.K. Park, T.J. Kang, Objective evaluation of seam pucker using artificial intelligence Part 1: Geometric modelings of seam pucker, Textile Research Journal, 69(10) (1999) 735-742.

[7] R.A.L. Miguel, J.M. Lucas, M.L. Carvalho, A.M. Manich, Fabric design considering the optimization of seam slippage, International Journal of Clothing Science and Technology, 17(3/4) (2005) 225-231.

[8] J.P. Domingues, A.A. Manich, R.M. Sauri, A. Barella, Assembling textile structures: wear simulation, International Journal of Clothing Science and Technology, 1997, 9(1) (1997) 75-87.

[9] K. Yildirim, Predicting seam opening behavior of woven seat fabrics, Textile Research Journal, 80(5) (2010) 472480.

[10] B.S. Gupta, F.J. Leek, R.L. Baker, D.R. Buchanan, T. Little, Directional variations in fabric properties and Seam quality, International Journal of Clothing Science and Technology, 1992, 4, (2/3) (1992) 71-78.

[11] D.G. Krasteva, H. Petrov, Investigation on the seam's quality by sewing of light fabrics, International Journal of Clothing Science and Technology, 20(1) (2008) 57-64.

[12] E. Malčiauskienè, A. Milašius, R. Milašius, Influence of Fabric Structure Parameters on Seam Slippage, Fibres \& Textiles in Eastern Europe, 20(3/92) (2012) 98-101.

[13] S. Brnada, B. Rogina-Car, S. Kovacevic, Influence of Woven Fabric Construction on Seam Thread Slippage, Journal of Fiber Bioengineering and Informatics, 9(4) (2016) 213-222.

[14] D. Bačkauskaitè, V. Daukantienè, S. Vaitkevičius, The Evaluation of Yarn Slippage at the Sewn Seam in Woven Fabrics Using the New Methods, Materials Science (Medziagotyra), 19(4) (2013) 420-427.

[15] H. Özdemir, D. Yavuzkasap, The effects of yarn and fabric structural parameters on the seam slippage, abrasion and pilling properties of double woven upholstery fabrics, Industria Textila, 63(6) (2012) 307-314.

[16] BS 3320:1990: "Determination of Slippage Resistance of Yarns in Woven Fabrics: Seam Method" 1990, ISBN-0 580 166570. 
Izvod

\section{UTICAJ GUSTOĆE POTKE, PODUŽNE MASE POTKE I DORADE} NA OTPORNOST KLIZANJA PREĐE U ŠAVU

Maja Jankoska, Goran Demboski

\section{Univerzitet "Sv. Kiril I Metodije”, Tehnološko-metalurški fakultet, Katedra za tekstil, Skopje, Makedonia}

Istraživan je uticaj gustoće potke, podužne mase potke i vodootporne i uljeodbojne dorade na svojstva klizanja šavova za grupu tkanina za stilsku odeću. Pokazano je da povećanje gustoće potke ima pozitivan efekat na svojstva klizanja šava, dok efekti zavise od veličine povećanja gustoće potke i smera ispitivanja. Uvođenje potke veće podužne mase rezultira poboljšanim performansama klizanja u smeru osnove. Kao rezultat veće podužne mase potke, otvaranje šavova se kod klizanja po osnovi smanjilo za $40 \%$. Tkanine s vodootpornom i uljeodbojnom završnom obradom pokazale su pogoršana svojstva klizanja šavova. Analiza varijanse potvrdila je da su gustoća potke, podužna masa potke i vodootporna i uljeodbojna dorada statistički značajni faktori otvaranja šavova kao posledica klizanja pređe u šavovima.
(ORIGINALNI NAUČNI RAD)

UDK 687.053.665:677.072

Ključne reči: klizanje šava, otvaranje šava, vodootporna i uljeodbojna dorada 